\title{
Biosimilars as a Future, Promising Solution for Financial Toxicity: A Review with Emphasis on Bevacizumab
}

\author{
Tabinda Saleem ${ }^{1}$, Hafiz Qurashi ${ }^{1}$, Munira Jamali ${ }^{2}$, Janet Chan Gomez ${ }^{1}$, Tejaswi Kanderi ${ }^{1}$ \\ 1. Internal Medicine, University of Pittsburgh Medical Center (UPMC) Pinnacle, Harrisburg, USA 2. Internal Medicine, \\ Dow Medical College, Dow University of Health Sciences (DUHS), Karachi, PAK
}

Corresponding author: Tejaswi Kanderi, tejaswi.kanderi@outlook.com

\begin{abstract}
A biosimilar is a biochemical product like another already approved biologic agent, known as the reference agent. To be endorsed by the Food and Drug Administration (FDA), biosimilars must demonstrate that they are as safe and effective as their reference item, with no clinical distinction. Humanized monoclonal antibodies $(\mathrm{mAb})$ are revolutionizing the treatment of gastrointestinal and gynecologic malignancies. Bevacizumab, trastuzumab, cetuximab, rituximab, and pegfilgrastim are the most widely used mAb products with oncologic indications. Due to the complexities of the regulatory system, it may take time for anticancer biosimilars to play a significant game-changing role. Over the last decade, the use of generics has saved billions of dollars every year, and it is expected that biosimilars will soon prove to be a cost-effective alternative and can play an important role in driving down healthcare costs globally.
\end{abstract}

In this review, we provide a critical appraisal of biosimilars with an emphasis on bevacizumab-awwb (Avastin) and its clinico-pharmacologic characteristics, safety, efficacy, interchangeability, regulatory and oncologic perspectives, and overall clinical perception.

Categories: Internal Medicine, Oncology, Public Health

Keywords: biosimilars, oncologic application, bevacizumab, cost effective therapy, commercialization, global oncology costs

\section{Introduction And Background}

A biosimilar is a biochemical with a composition similar to a reference biologic agent and is approved for use in the United States (U.S.) by the Food and Drug Administration (FDA) [1]. For a product to be rendered as a biosimilar, there should be no clinically significant differences with its reference biologic agent. Apart from minor contrasts, the safety, efficacy, potency, and immunogenicity of the two should remain indistinguishable [2].

Received 07/06/2020

Review began $07 / 07 / 2020$ Review ended 07/10/2020 Published 07/20/2020

๑) Copyright 2020 Saleem et al. This is an open access article distributed under the terms of the Creative Commons Attribution License CC-BY 4.0., which permits unrestricted use, distribution, and reproduction in any medium, provided the original author and source are credited.
For a decade, biosimilars have been a fundamental part of clinical practice in the European Union. In 2006, somatropin (recombinant human growth hormone) was the first biosimilar introduced by the European Medicines Agency (EMA), followed by biosimilars for epoetin alfa and filgrastim over the next few years [3]. Furthermore, the introduction of biosimilar adalimumab in 2017 has led to an almost $80 \%$ reduction in the use of biologic adalimumab (Humira). Till now, a total of 16 biosimilars are available in the European market and many more are reported to be under process. On the other hand, in the United States, the FDA has approved 17 biosimilars so far but only seven are commercially available with filgrastim-sndz (Zarxiom) being the first one [4].

Currently, the pioneer manufacturers of biosimilars are in the United States, Europe, and Israel, whereas India, China, and Brazil have emerging manufacturers [5-6]. Many of the oncologic biologics have lost or are in danger of losing their patent protection, and to overcome this loss, new biosimilars are being developed [7-9]. The driving force behind the rapid advancement and introduction of biosimilars into the market is to increase the availability of cost-effective alternatives to biologics and thereby decrease overall health care costs, inciting the authorities to have a more optimistic impression on the biosimilars. In fact, as part of the current administration's efforts to lower drug prices, the FDA has released plans for the easier approval and marketing of biosimilars in the past; nonetheless, disputes between the makers of biologic drugs and biosimilar manufacturers are cited to cause delays in the actual implementation.

\section{Review}

Out of the seven biosimilars approved for use in the United States, Zarxiom (filgrastim-sndz), a biosimilar to the granulocyte stimulating factor, filgrastim, was the first biosimilar to be approved in 2015, Please refer to Table 1 [10]. Additionally, pegfilgrastim-jmdb and the pegfilgrastim Lapelga (approved in Canada) are in the process of undergoing the administrative audit process [11-13]. As of late 2019, 25 biosimilars have been affirmed in the European Union (EU). Of them, none have demonstrated any distinction in the safety, 


\section{Cureus}

adequacy, or frequency of adverse responses with the respective reference biologics when monitored over the course of 10 years. Whereas in the United States, as of late 2019, three biosimilar mAbs have been endorsed and are widely used; interestingly, their use is limited to chronic inflammatory conditions like rheumatoid arthritis, psoriatic arthritis, inflammatory bowel disease, etc., instead of oncologic indications. Infliximab-dyyb, a biosimilar of the tumor necrosis factor-alpha (TNF-alpha) inhibitor, Infliximab, is the first in this class and is the second biosimilar in the U.S. to get FDA endorsement [14]. Three ancillary TNFalpha inhibitor biosimilars, etanercept-szzs, adalimumab-atto, and infliximab-abda, have FDA endorsement but are pending accessibility in the United States due to patent rights [15-17].

\begin{tabular}{|c|c|c|c|c|}
\hline Biosimilar & $\begin{array}{l}\text { Reference } \\
\text { Drug }\end{array}$ & $\begin{array}{l}\text { FDA } \\
\text { Approval } \\
\text { Timeline }\end{array}$ & $\begin{array}{l}\text { Mechanism of } \\
\text { Action(s) }\end{array}$ & Clinical Indications \\
\hline $\begin{array}{l}\text { Filgrastim- } \\
\text { sndz1 (Zarxio) }\end{array}$ & $\begin{array}{l}\text { Filgrastim } \\
\text { (Neupogen/ } \\
\text { Amgen) }\end{array}$ & 2015 & $\begin{array}{l}\text { Granulocyte } \\
\text { colony- } \\
\text { stimulating } \\
\text { factor }\end{array}$ & $\begin{array}{l}\text { Acute myeloid leukemia, Severe neutropenia, patient on chronic } \\
\text { immunosuppressive therapy, or those undergoing stem cell or bone } \\
\text { marrow transplant. }\end{array}$ \\
\hline $\begin{array}{l}\text { Infliximab- } \\
\text { dyyb } \\
\text { (Inflectra) }\end{array}$ & $\begin{array}{l}\text { Infliximab } \\
\text { (Remicade) }\end{array}$ & 2016 & $\begin{array}{l}\text { Tumor necrosis } \\
\text { factor-alpha } \\
\text { inhibitor }\end{array}$ & $\begin{array}{l}\text { Juvenile idiopathic arthritis, Rheumatoid arthritis, Inflammatory bowel } \\
\text { disease (Crohn's disease or ulcerative colitis), and seronegative } \\
\text { spondyloarthropathies. }\end{array}$ \\
\hline $\begin{array}{l}\text { Etanercept- } \\
\text { szzs (Erelzi) }\end{array}$ & $\begin{array}{l}\text { Etanercept } \\
\text { (Enbrel) }\end{array}$ & 2016 & $\begin{array}{l}\text { Tumor necrosis } \\
\text { factor-alpha } \\
\text { inhibitor }\end{array}$ & $\begin{array}{l}\text { Severe active psoriatic disease, juvenile idiopathic arthritis, severe } \\
\text { polyarticular juvenile idiopathic disease. }\end{array}$ \\
\hline $\begin{array}{l}\text { Adalimumab- } \\
\text { atto } \\
\text { (Amjevita) }\end{array}$ & $\begin{array}{l}\text { Adalimumab } \\
\text { (Humira) }\end{array}$ & 2016 & $\begin{array}{l}\text { Tumor necrosis } \\
\text { factor-alpha } \\
\text { inhibitor }\end{array}$ & $\begin{array}{l}\text { Rheumatoid arthritis, severe seronegative polyarticular disease, and } \\
\text { inflammatory bowel disease }\end{array}$ \\
\hline $\begin{array}{l}\text { Infliximab- } \\
\text { abda } \\
\text { (Renflexis) }\end{array}$ & $\begin{array}{l}\text { Infliximab } \\
\text { (Remicade) }\end{array}$ & 2017 & $\begin{array}{l}\text { Tumor necrosis } \\
\text { factor-alpha } \\
\text { inhibitor }\end{array}$ & $\begin{array}{l}\text { Inflammatory bowel disease, rheumatoid arthritis, seronegative } \\
\text { spondyloarthropathies. }\end{array}$ \\
\hline $\begin{array}{l}\text { Trastuzumab- } \\
\text { dkst (Ogivri) }\end{array}$ & $\begin{array}{l}\text { Trastuzumab } \\
\text { (Herceptin) }\end{array}$ & 2017 & $\begin{array}{l}\text { HER2 receptor } \\
\text { inhibitor }\end{array}$ & $\begin{array}{l}\text { HER2 receptor-positive metastatic breast disease, gastro-esophageal } \\
\text { junction metastatic disease. }\end{array}$ \\
\hline $\begin{array}{l}\text { Epoetin Alfa- } \\
\text { epbx } \\
\text { (Retacrit) }\end{array}$ & $\begin{array}{l}\text { Epoetin Alfa } \\
\text { (Epogen/ } \\
\text { Procrit) }\end{array}$ & 2018 & Erythropoietin & Anemia, cancer, chronic kidney failure \\
\hline $\begin{array}{l}\text { Pegfilgrastim- } \\
\text { jmdb } \\
\text { (Fulphilia) }\end{array}$ & $\begin{array}{l}\text { Pegfilgrastim } \\
\text { (Neulasta) }\end{array}$ & 2018 & $\begin{array}{l}\text { Granulocyte } \\
\text { colony- } \\
\text { stimulating } \\
\text { factor }\end{array}$ & $\begin{array}{l}\text { Decrease the risk of infection in non-myeloid cancer who are receiving } \\
\text { myelosuppressive chemotherapy }\end{array}$ \\
\hline $\begin{array}{l}\text { Filgrastim- } \\
\text { aafi } \\
\text { (Nivestym) }\end{array}$ & $\begin{array}{l}\text { Filgrastim } \\
\text { (Neupogen) }\end{array}$ & 2018 & $\begin{array}{l}\text { Leukocyte } \\
\text { growth factor }\end{array}$ & $\begin{array}{l}\text { Reduce the frequency of febrile neutropenia and infections in patients } \\
\text { with non-myeloid malignancies receiving immune-suppressive therapy. }\end{array}$ \\
\hline
\end{tabular}

\section{TABLE 1: A summary list of the biosimilars currently affirmed in the United States and their proposed indications}

Source: [18]

FDA: U.S. Food and Drug Administration; HER2: human epidermal growth factor receptor 2

Biosimilars for a complex biologic monoclonal antibody (mAbs) that are extensively utilized in the management of cancers (like trastuzumab, bevacizumab, rituximab, and cetuximab) are in the late phases of clinical advancement and are demonstrating comparative clinical efficacy to their reference [19-20]. Please refer to Table 2. 


\section{Cureus}

\begin{tabular}{|c|c|c|c|c|}
\hline $\begin{array}{l}\text { Product } \\
\text { Name }\end{array}$ & Biosimilar & $\begin{array}{l}\text { Class / } \\
\text { Mechanism } \\
\text { of Action(s) }\end{array}$ & Current Status & Clinical Indication \\
\hline Bevacizumab & $\begin{array}{l}\text { BCD-021 } \\
\text { ABP } 215 \text { CT- } \\
\text { P16 TAB008 }\end{array}$ & $\begin{array}{l}\text { VEGF } \\
\text { inhibitor }\end{array}$ & $\begin{array}{l}\text { Phase III initial trial approved for CT- } \\
\text { P16 }\end{array}$ & $\begin{array}{l}\text { Colorectal metastatic disease, NSCLC, renal } \\
\text { cell metastatic disease, glioblastoma, } \\
\text { epithelial cervical, ovarian, and fallopian tube } \\
\text { cancers. }\end{array}$ \\
\hline Trastuzumab & $\begin{array}{l}\text { Myl-14010 } \\
\text { ABP } 980 \text { CT- } \\
\text { P6 BCD-022 } \\
\text { SB3 }\end{array}$ & $\begin{array}{l}\text { HER2 } \\
\text { inhibitor }\end{array}$ & $\begin{array}{l}\text { Phase III trial CT-P6 exhibited } \\
\text { proportionate viability, safety; FDA } \\
\text { endorsement pending }\end{array}$ & HER2-positive metastatic breast cancer. \\
\hline Rituximab & $\begin{array}{l}\text { GP2013 } \\
\text { BCD-020 CT- } \\
\text { P10 RTXM83 }\end{array}$ & $\begin{array}{l}\text { CD20 } \\
\text { inhibitor }\end{array}$ & $\begin{array}{l}\text { BCD-020 and RTXM83 demonstrated } \\
\text { equivalent efficacy \& safety in phase III } \\
\text { trial; Others Listed/ ongoing FDA } \\
\text { review. }\end{array}$ & Follicular lymphoma, DLBCL and NHL \\
\hline Cetuximab & $\begin{array}{l}\text { ABP } 494 \text { STI- } \\
001\end{array}$ & $\begin{array}{l}\text { EGFR } \\
\text { inhibitor }\end{array}$ & ABP494 in phase III trial & Colorectal cancer \\
\hline Pegfilgrastim & $\begin{array}{l}\text { LA-EP2006 } \\
\text { CHS-1701 } \\
\text { MYL-1401H } \\
\text { Lapelga }\end{array}$ & $\begin{array}{l}\text { Pegylated } \\
\text { G-CSF }\end{array}$ & $\begin{array}{l}\text { MYL1401H, CHS-1/01 acknowledged } \\
\text { for FDA assessment. }\end{array}$ & $\begin{array}{l}\text { Long-acting formulation of Filgrastim. Reduce } \\
\text { the frequency of infections in patients } \\
\text { compelling myelosuppressive therapy }\end{array}$ \\
\hline
\end{tabular}

TABLE 2: A summary of oncology biosimilars in phase III trial in the United States includes either completed or underway products

Source: [18]

VEGF: vascular endothelial growth factor; HER2: human epidermal growth factor receptor 2; CD: cluster differentiation; EGFR: endothelial growth factor receptors; GCSF: granulocyte colony-stimulating factor; NSCLC: non-small-cell lung cancer; DLBCL: diffuse large B cell lymphoma; NHL: non-Hodgkin lymphoma

\section{Bevacizumab-awwb}

Bevacizumab is a recombinant humanized monoclonal (IgG1) antibody that binds the vascular endothelial growth factor (VEGF) and prevents its interaction with VEGF receptor-1, and VEGF receptor-2 on the endothelial cell surface, resulting in angiogenesis inhibition preventing the growth and development of tumors as represented by Figure 1 . 


\section{Cureus}

FDA

\section{Approved} Indications

\section{Combination Chemotherapy}

Type of Cancer

Intravenous 5-fluorouracil

First-line

treatment

First-line

treatment

First-line

treatment

First-line

treatment

Second-line

treatment
Fluoropyrimidine-irinotecan or

fluoropyrimidine-oxaliplatin

Carboplatin and paclitaxel

Interferon-alpha

Topotecan and paclitaxel or cisplatin and paclitaxel

Monotherapy
Colorectal metastatic disease

Advanced, unresectable or recurrent non-small cell lung cancer

Renal cell metastatic disease

Advanced, recurrent or persistent cervical cancer

Glioblastoma
Indication for Second-Line Treatment

Patients who have progressive disease despite maximum therapy with bevacizumab.

Patients with metastatic brain disease or on anticoagulant therapy

Nonresponder to initial therapy with other VEGF inhibitors

To improve median survival with first-line chemotherapy

Indicated for resistant and progressive disease in adult patients

\section{TABLE 3: Bevacizumab indications}

VEGF: vascular endothelial growth factor 
FDA endorsed bevacizumab-awwb (ABP215 or MvasiTM), a biosimilar, in 2017 and since then it has been reported as an equally effective alternative to bevacizumab for treating various kinds of malignancies. Apsangikar et al. observed that biosimilar bevacizumab-awwb was non-inferior to the reference drug in treating metastatic colorectal cancer [22].

Similar outcomes are also reported between ABP-125 and the bevacizumab reference product in the treatment of advanced non-small-cell lung cancer in a phase III trial (the MAPLE study), conducted in Canada from 2015-2018 [23]. This randomized, double-blind, phase III comparative trial showed a response rate risk ratio of 0.93 with a $90 \%$ confidence interval (CI) between $0.80-1.09$, which was similar for both Avastin and bevacizumab ABP-125 meeting the primary endpoint [23].

To date, many biosimilars of bevacizumab, with equal efficacy to Avastin, are reported to be in development globally. In a phase I clinical trial in China, bevacizumab biosimilars MIL 60, BAT1706, and IB1305 showed similar biochemical properties and biological functions. Pharmacokinetic (PK) profiles have a bioequivalence acceptance range of $80 \%-125 \%$ in comparison with the reference bevacizumab - EU.

In June 2018, a biopharmaceutical organization in South Korea, Celltrion, finished a phase I study on CTP16's (biosimilar of bevacizumab) safety and pharmacokinetic evaluation. Clinical Trial Application (CTA) for phase III preliminary was presented to Portugal's National Authority of Medicines \& Health Products, I.P. (Infarmed) with the idea to set phase III trials in 20 nations with more than 150 multi centers

In 2019, a phase I randomized a single-dose study conducted in China to evaluate the efficacy of TAB008 also showed similar pharmacokinetics and safety to Avastin.

\section{Need for biosimilars}

Biologics have become an integral part of many chemotherapeutic regimens. The spectrum of products, particularly the monoclonal antibodies, require a highly precise and expensive manufacturing process. The rising cost of cancer treatment (referred to as financial toxicity) and complex manufacturing processes limit their use, especially in developing countries. The expiration of patents for many biologics has paved the need for the development of corresponding biosimilars [1].

Biosimilars are novel structures that are planned to be profoundly like and treat similar conditions as a current biologic agent [24-25]. Biosimilars may offer expanded treatment alternatives for patients and physicians and can improve efficiencies across the healthcare system around the world. Biosimilars may also considerably bring down the cost of biologics and, consequently, increase the utilization of biologic treatments. This may further enhance clinical results and give more options to the prescribers, pharmaceuticals, and insurance companies and would overall abate the rising financial toxicity in the society.

\section{Cost-effectiveness of biosimilars}

The expanded use of biologic agents in cancer treatment is contributing to the continued rise in U.S. healthcare costs, with limited access. The Intercontinental Marketing Statistics (IMS) wellbeing report published in 2016 predicted that the global spending on oncology drugs will surpass $\$ 150$ billion by 2020 , with a yearly increase in the rate of up to $10.5 \%$ [26]. Please refer to Figure 2.

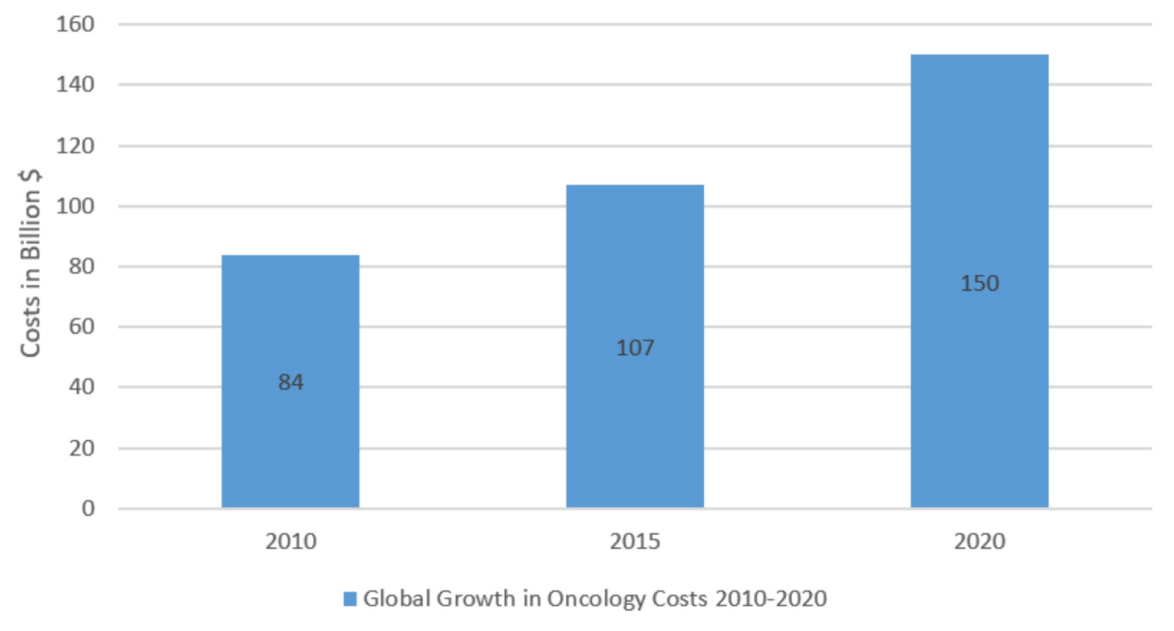


Since the establishment of the Biologics Price Competition and Innovation Act (BPCIA) in 2010, biosimilars have been created and showcased as aggressive, cost-effective alternatives to biologic medications [27-28]. Economists have noted that the accessibility of biosimilars may bring down the social insurance consumptions.

Eight of the 10 expensive medications currently available are used for cancer therapy. The monoclonal antibodies, bevacizumab, rituximab, and trastuzumab, are among the top- 20 most expensive neoplastic drugs used in outpatient cancer centers, with the assessed worldwide expenditure of $\$ 5.6$ billion for bevacizumab, $\$ 5.1$ billion for trastuzumab, and $\$ 7.5$ billion for infliximab [29]. Although only $15 \%$ of the agents listed in the National Comprehensive Cancer Network (NCCN) Drugs and Biologics Compendium are biologic agents, they dominate the drug therapy expenditure in the U.S. [27]. The patent for every one of these medications will expire within the next five years, thus necessitating the need for biosimilars, with encouraging results with biosimilars for bevacizumab. Expanding the use of these agents can lead to a significant decrease in the expense of cancer treatment, which eventually would reduce the insurance costs and co-pays for patients. However, the window for these biosimilars to have an impact on healthcare costs is narrowing owing to delays in market introduction and utilization. Advanced, more expensive treatments are taking the place of current biologics, lessening the financial impact of current biosimilars [30]. For biosimilars to cause significant flattening of the cost-expenditure curve, strong acknowledgment of their efficacy is needed by oncologists and their patients globally.

\section{Conclusions}

We believe biosimilars have vast opportunities in the future, but bringing them to a level that ensures wide availability in the market is a long road ahead considering the costs. However, now that the key stakeholders are starting to better understand and accept biosimilars, it can result in more tolerant regulations and legislations that can ultimately lead to an increase in the utilization of biosimilars in the United States. We strongly believe that understanding the concept of biosimilars is crucial for oncologists.

\section{Additional Information \\ Disclosures}

Conflicts of interest: In compliance with the ICMJE uniform disclosure form, all authors declare the following: Payment/services info: All authors have declared that no financial support was received from any organization for the submitted work. Financial relationships: All authors have declared that they have no financial relationships at present or within the previous three years with any organizations that might have an interest in the submitted work. Other relationships: All authors have declared that there are no other relationships or activities that could appear to have influenced the submitted work.

\section{References}

1. Nabhan C, Parsad S, Mato AR, Feinberg BA: Biosimilars in oncology in the United States. A review . JAMA Oncol. 2018, 4:241-247. 10.1001/jamaoncol.2017.2004

2. Belsey MJ, Harris LM, Das RR, Chertkow J: Biosimilars: initial excitement gives way to reality. Nat Rev Drug Discov. 2006, 5:535-536. 10.1038/nrd2093

3. Generics and Biosimilars Initiative. EU guidelines for biosimilars . (2016). http://www.gabionline.net/Guidelines/EU-guidelines-for-biosimilars.

4. US FDA approves first biosimilar product Zarxio, the first biosimilar approved in the U.S . (2018). https://www.policymed.com/2015/03/fda-approves-sandozs-zarxio-the-first-biosimilar-approved-in-theus.html.

5. PharmPro. Top 25 biosimilar drug manufacturers. (2016). https://www.pharmpro.com/news/2016/05/top-25biosimilar-drug-manufacturers.

6. Visiongain: Pharma leader series: 25 top biosimilar drug manufacturers 2016-2026. (2016). https://www.visiongain.com/report/pharma-leader-series-25-top-biosimilar-drug-manufacturers-20162026/.

7. Mellstedt H: Anti-neoplastic biosimilars--the same rules as for cytotoxic generics cannot be applied . Ann Oncol. 2013, 24:23-28. 10.1093/annonc/mdt325

8. Li E, Subramanian J, Anderson S, Thomas D, McKinley J, Jacobs IA: Development of biosimilars in an era of oncologic drug shortages. Drug Des Devel Ther. 2015, 9:3247-3255. 10.2147/dddt.S75219

9. Chopra R, Lopes G: Improving access to cancer treatments: the role of biosimilars . J Glob Oncol. 2017, 3:596-610. 10.1200/igo.2016.008607

10. American Society of Clinical Oncology: The state of cancer care in America, 2016: a report by the American Society of Clinical Oncology. J Oncol Pract. 2016, 12:339-383. 10.1200/jop.2015.010462 
11. Generics and Biosimilars Initiative. Biosimilars of pegfilgrastim . (2019). http://www.gabionline.net/Biosimilars/General/Biosimilars-of-pegfilgrastim.

12. Generics and Biosimilars Initiative. FDA accepts application for Mylan/Biocon's pegfilgrastim biosimilar . (2017). http://www.gabionline.net/Biosimilars/News/FDA-accepts-application-for-Mylan-Biocon-spegfilgrastim-biosimilar.

13. Pegfilgrastim biosimilars in the pipeline. (2016). https://www.centerforbiosimilars.com/news/supportivecare-in-oncology-therapy-pegfilgrastim-biosimilars-in-the-pipeline-.

14. Park W, Hrycaj P, Jeka S, et al.: A randomised, double-blind, multicentre, parallel-group, prospective study comparing the pharmacokinetics, safety, and efficacy of CT-P13 and innovator infliximab in patients with ankylosing spondylitis: the PLANETAS study. Ann Rheum Dis. 2013, 72:1605-1612. 10.1136/annrheumdis2012-203091

15. FDA. FDA News Release. FDA approves Inflectra, a biosimilar to Remicade . (2016). https://www.fda.gov/news-events/press-announcements/fda-approves-inflectra-biosimilar-remicade.

16. Biosimilars Resource Center. FDA approves Erelzi, a biosimilar to Enbrel . (2016). https://www.biosimilarsresourcecenter.org/fda-approves-erelzi/.

17. Biosimilars Resource Center. FDA approves Amjevita, a biosimilar to Humira . (2016). https://www.biosimilarsresourcecenter.org/fda-approves-amjevita/.

18. Statista. Total global biologics spending from 2002 and 2017 (in billion U.S. dollars) . (2018). https://www.statista.com/statistics/280578/global-biologics-spending/.

19. Kumar R, Singh J: Biosimilar drugs: current status . Int J Appl Basic Med Res. 2014, 4:63-66. 10.4103/2229516x.136774

20. Rifkin RM, Peck SR: Biosimilars: implications for clinical practice. J Oncol Pract. 2017, 13:24-31. 10.1200/jop.2017.025734

21. Monk BJ, Huh WK, Rosenberg JA, Jacobs I: Will bevacizumab biosimilars impact the value of systemic therapy in gynecologic cancers?. Gynecol Oncol Res Pract. 2017, 4:7. 10.1186/s40661-017-0045-X

22. Apsangikar P, Chaudhry S, Naik M, Deoghare S, Joseph J: Comparative pharmacokinetics, efficacy, and safety of bevacizumab biosimilar to reference bevacizumab in patients with metastatic colorectal cancer. Indian Journal of Cancer. 2017, 54:535-538. 10.4103/ijc.IJC_394_17

23. Thatcher N, Goldschmidt JH, Thomas M, et al.: Efficacy and safety of the biosimilar ABP 215 compared with bevacizumab in patients with advanced nonsquamous non-small cell lung cancer (MAPLE): a randomized, double-blind, phase III study. Clin Cancer Res. 2019, 25:2088-2095. 10.1158/1078-0432.Ccr-18-2702

24. FDA. Scientific considerations in demonstrating biosimilarity to a reference product . (2015). https://www.fda.gov/regulatory-information/search-fda-guidance-documents/scientific-considerationsdemonstrating-bios....

25. European Medicines Agency. Guideline on similar biological medicinal products containing biotechnologyderived proteins as active substance: non-clinical and clinical issues. (2014). https://www.ema.europa.eu/en/documents/scientific-guideline/guideline-similar-biological-medicinalproducts-containin....

26. eHealthcare Solutions. New IMS report reveals global cancer drug spending to exceed 150 billion by 2020 . (2016). https://ehealthcaresolutions.com/new-ims-report-reveals-global-cancer-drug-spending-exceed150-billion-2020/.

27. Daller J: Biosimilars: a consideration of the regulations in the United States and European Union . Regul Toxicol Pharmacol. 2016, 76:199-208. 10.1016/j.yrtph.2015.12.013

28. Olech E: Biosimilars: rationale and current regulatory landscape. Semin Arthritis Rheum. 2016, 45:1-10. 10.1016/j.semarthrit.2016.01.001

29. Nabhan C, Feinberg BA: Behavioral economics and the future of biosimilars. J Natl Compr Canc Netw. 2017, 15:1449-1451. 10.6004/jnccn.2017.7023

30. Gellad WF, Good CB: Adalimumab and the challenges for biosimilars . JAMA. 2019, 322:2171-2172. 10.1001/jama.2019.16275 